\title{
The Influence of Emotional Intelligence, Moral Intelligence and Intellectual Intelligence on Characters Caring for the Environmental School Students in the Perspective of Civic Education
}

\author{
Rhindra Puspitasari ${ }^{1, *}$, Dasim Budimansyah ${ }^{2}$,Sapriya Sapriya ${ }^{3,}$ Rahmat Rahmat ${ }^{4}$
}

1,2,3,4 Universitas Pendidikan Indonesia, Bandung, Indonesia

*Corresponding author.Email: rhindra.puspitasari@upi.edu

\begin{abstract}
The purpose of this study was to determine the effect of: emotional intelligence, moral intelligence, and intellectual intelligence on the environmental care character of elementary school students in Temanggung district in the perspective of civic education, both partially and simultaneously. This type of research is causal-associative with a quantitative approach. The study population was the fifth grade elementary school students, amounting to 550 students. A sample of 200 students was taken using cluster stratified random sampling technique. Data on emotional intelligence, moral intelligence and intellectual intelligence were collected through a questionnaire, while data on students' environmental care character were collected through tests and documentation. The research data were analyzed using multiple regression techniques. This study concludes four findings. First, there is a positive effect of emotional intelligence on students' environmental care character $(\mathrm{t}=2.279$ and sig. $=0.023<0.05)$. Second, there was no effect of intellectual intelligence on students' environmental care character $(t=-0.347$ and sig. $=0.729>0.05)$. Third, there is a positive effect of moral intelligence on students' environmental care character $(\mathrm{t}=3.667$ and sig. $=$ $0.000<0.05$ ). Fourth, there is a joint influence of emotional intelligence, moral intelligence and intellectual intelligence on the environmental care character of elementary school students $(F=5,982$ and sig. $=0.001<0.05)$. The three independent variables together have an effect (adjusted by $5.0 \%$ on the environmental care character of elementary school students in Temanggung Regency.
\end{abstract}

Keywords: Character care for environment, Civic Education, Emotional Intelligence, Intellectual Intelligence, Moral Intelligence.

\section{INTRODUCTION}

The intelligence of citizens at this time is something that is urgent to be developed. Citizens who are not intelligent can cause social problems and environmental problems both in the local and global realm. Environmental problems that arise as a result of people who are not intelligent are certainly very detrimental to the current generation and the next generation. According to Douglas Schuler, citizen intelligence or civil intelligence is a new hope to build a better world, of course starting from personal intelligence, collective intelligence and global society intelligence[1]. The success of a living environment that is able to support people's lives such as economic strength, cleanliness of the living environment, harmony between residents shows that civil intelligence in the area is high [2].
Developing the intelligence of citizens is included in efforts to realize the goal of the Unitary State of the Republic of Indonesia, namely the intellectual life of the nation. One of the steps that can be pursued is through education. It becomes unique and holistic when what is developed is not only intellectual and psychic intelligence. However, the moral, emotional and spiritual intelligence of students or students. UNESCO data shows that it is necessary to protect and preserve the environment, because $42 \%$ of students aged between 6-12 years have very little knowledge and behavior that shows they care about the environment [3].

Awareness of protecting the environment is strongly influenced by a person's social intelligence [4]. Social, emotional, spiritual and moral intelligence needs to be developed from an early age. One of them is through Citizenship Education. Citizenship Education ( $\mathrm{PKn})$ is 
an appropriate subject to increase the intelligence of citizens. Civic intelligence in it consists of components related to social intelligence which of course has an important role in citizen behavior that produces civic virtue [5].

The intelligence of citizens in this case includes emotional intelligence, moral intelligence and intellectual intelligence. In its development, emotional intelligence is no less important than intellectual intelligence. As stated by Goleman, emotional intelligence is a distinctive intelligence that involves feelings that are strongly influenced by the environment, which are permanent but can change at any time [6]. While intellectual intelligence is more logical and is formed by the left brain which includes linear, mathematical and logical systematic intelligence.

Moral intelligence refers to the ability to act and behave right or wrong in accordance with the standards of moral norms that apply in society. In the context of maintaining environmental sustainability, it is important to develop a caring character for the environment [7].

Citizens are not only important to be intellectually intelligent, but also intelligent in the habit of protecting the environment. Building a character who cares about the environment requires smart citizens, this method is one solution based on recommendations from several experts who describe that the habits of children who are in a supportive environment will jump-start their cognitive, social and emotional intelligence potential as stated by [8] that attitude and intelligent behavior as citizens must be trained and formed as early as possible, one of which is through concern for nature through direct involvement [9]. In line with Taylor, Williams recommends that through education with a varied model it is easier for the 21 st century generation to be involved in the environmental movement [10].

\section{THEORETICAL REVIEW}

\subsection{Part of Civic Intelligence (Emotional Intelligence, Moral Intelligence and Intellectual Intelligence)}

In the study of Citizenship Education, the definition of civic intelligence which includes emotional intelligence, moral intelligence and intellectual intelligence refers to the cooperative theory presented by John Dewey [11]. Dewey explained that cooperative intelligence or civil intelligence is not only born of intellectual intelligence, but also moral intelligence and personality [12]. Schuler further explained that civic intelligence is a form of collective intelligence that can be developed by individuals through the development of mastery of citizenship competencies [13].

So the definition of civic intelligence in this study is intelligence that includes aspects of intellectual intelligence, emotional intelligence, moral and spiritual intelligence in the mastery of civic competence. Science, according to him, does not need to be obtained from books, but must be given to students through functional and useful tasks [14]. Dewey is deeply connected to meaningful learning by rewarding values. What is implied here does not imply that he is calling to antagonize intellectualism, but to exploit the way people must be dynamic, attentive and ready to investigate.

Learning must underscore practice and experimentation [15]. Overall, learning must be adapted as a foundation for development, after all learning as a continuation of brain development and continuation of life development. The learning objectives are social skills with skills sharing strategies to participate in exercises for the satisfaction of normal interests and unconditional and ideal government assistance [16].

Replacing the idea of a majority rule system in learning, Dewey said that in learning interactions students should be given the opportunity to make remarks. Understanding must be dynamic and not just acknowledge the information provided by the educator. In addition, educators are obliged to provide an environment that aims to keep students excited about information. The premise of popular government is belief in his abilities as individuals.

That is, belief in human knowledge as in the power of encounters and cooperative encounters. The premise of the majority rule system is that real-life decisionmaking opportunities (and experiences) are essential for making smart opportunities [17].

In John Dewey's way of thinking, it is stated that the existence of a continuum of experimentation or development of unified encounters, is a cycle of improvement which initially as a matter of fact drives motivation about tendencies and self for the relationship between information and understanding, as well as relearning as social interaction. For John Dewey, popular government is not just an opportunity in real life, but above all an opportunity for knowledge. Dewey says that: unless the opportunity for activity is (guided) by insight, its practical indication is bound to bring chaos and confusion [18].

Consequently, the majority set the government's obligation to the opportunity of insight to be more important than the opportunity to take part. John Dewey is a way of thinking to realize who sees the closest relationship between learning and sound-based systems. acceptance cannot be separated from reputation-based state organizations[19]. Studying popular government as a conscious effort to shape the ability of the nation's individuals to participate competently in the existence of the state and the state is important. 
With high cooperation from individuals in the existence of the state and the state, it can encourage the realization of a straightforward and responsible government. Such a government will only be formed if its citizens have cooperative and collective intelligence. Intelligent citizens can be formed through strengthening civic intelligence, of course by increasing the mastery of citizenship competencies.

\subsection{Environmental Care Character Values}

Reflections on ecological and environmental citizenship are closely related to citizen behavior. Because through environmental-based citizenship, citizens are given information about their duties to protect and protect the environment. Obviously, this is not just informational or intellectual, but the main thing is how the use of that information turns into a real activity. The type of teaching civic education based on its natural environment is in a family, school and community environment that is centered on the population as a whole, for example, discussing, acting, differing opinions, asking openly [20].

Dobson's method in ecological citizenship is used to increase participation in protecting the environment and climate. Ecological Citizenship should be characterized as training that emphasizes making residents aware of their rights and commitment to environmental sustainability [21]. So to save the environment in the future it is more effective to change the person's awareness to love the environment. Environmentally friendly characters cannot be obtained in an instant or instantly, but require a long process and a complex range of steps. An individual can have a caring attitude and love the environment because it goes through an iterative process of change.

Changes that occur consistently so that it will be firmly planted in his brain, and his behavior so that later it will always be conveyed in every change of the day according to the character values it has. A young person with a very environmental-centered character will affect the versatility of the surrounding environment. The completely environment-centered character that was introduced early on wouldn't wear off as effectively as he grew up.

Of course, even with the right instructions, this character will grow even further. $\mathrm{He}$ will think positively as a general rule of the existence of living things and the surrounding air as an interconnected climate that must be guaranteed. Furthermore, the organic system that surrounds it will be secured so that it is not easily damaged and makes common parasites everywhere. This is where it is important to anticipate natural disaster events early on [22]. Character education related to the environment must be appointed as a work to instill biological awareness from the beginning.

Schools are formal foundations that are obliged to add encouraging character values related to the love of nature which aims to hold the environment from being harmed and saved [23]. So it would generally be assumed that truly focusing on the environment is a mindset and practice adopted by people to reliably try to ensure, prevent and secure the surrounding environment and welcome others to save the environment. As pointed out by [24] mentions the environment is something related to objects, forces, conditions, circumstances, and their influence on the space we have and living things including human life.

\section{METHODS}

This research is an expost facto research, the data in the research is obtained from the data of events that have taken place and the researcher does not manipulate or treat the existing variables. In other words, the researcher reveals the facts based on the symptoms that exist in the respondent. The research model used in this research is causal-associative research.

Where the formulation of the problem is a causal relationship problem, namely a causal relationship, so that there are independent variables (influenced variables) and dependent variables (influenced variables). The population is 550 students while the sample is 200 students. Population student grade V elementary school in Temanggung regency and sample was done selected by cluster stratified random sampling [25].

Table 1. State of Population

\begin{tabular}{|l|l|c|}
\hline No & Name of School & The Number of Student \\
\hline 1. & SDN Kowangan & 40 \\
\hline 2. & SD IT Parakan & 40 \\
\hline 3. & SDN Muntung & 40 \\
\hline 4. & SD Islam Ngadirejo & 40 \\
\hline 5. & SD N 2 Kedu & 40 \\
\hline \multicolumn{2}{|l|}{ Total } & 200 \\
\hline
\end{tabular}

Source: Elementary School in Temanggung Regency 2021

Data collection techniques using documentation, written tests and questionnaires. While the data analysis technique uses the validity and reliability of the instrument as well as item analysis. Testing the hypothesis used, using simple regression analysis to determine the effect of the dependent variable on the independent variable. Hypothesis testing was carried out using multiple regression techniques. As the criteria for rejection and acceptance of the hypothesis using a significance level of $5 \%$. The regression equation in this study is as follows: 


$$
a+b_{1} X_{1}+b_{2} X_{2}+b_{3} X_{3}+e=\gamma
$$

$a=$ constanta value

$b_{1}=$ value of beta coefficient emotional intelligence

$b_{2}=$ value of beta coefficient intellectual intelligence

$b_{3}=$ value of beta coefficient moral intelligence

$X_{1}=$ emotional intelligence

$X_{2}=$ moral intelligence

$X_{3}=$ intellectual intelligence

\section{RESULTS AND DISCUSSION}

F Primary data was obtained by using a questionnaire distributed to 200 respondents or students. The variables in the primary data consist of emotional intelligence $\left(\mathrm{X}_{1}\right)$, moral intelligence $\left(\mathrm{X}_{2}\right)$, intellectual intelligence $\left(\mathrm{X}_{3}\right)$ and environmental care character $(\mathrm{Y})$ for fifth grade elementary school students. In this study, the sample consisted of 5 schools in Temanggung. The calculations uses SPSS 16 for Windows, 95\% confident level $\alpha=0.05$ the data significant if $\alpha<0.05$, with the following result:

Tabel 2. Multiple Linear Regression Test

\begin{tabular}{|c|c|c|c|c|}
\hline $\begin{array}{l}\text { Variabl } \\
\mathrm{e}\end{array}$ & $\begin{array}{l}\text { Unstandarize } \\
\text { d coefficient } \\
\text { B }\end{array}$ & $\mathrm{T}$ & Sig & $\begin{array}{l}\text { infomatio } \\
n\end{array}$ \\
\hline$\left(\mathrm{X}_{1}\right)$ & 0.304 & $\begin{array}{l}2.27 \\
9\end{array}$ & $\begin{array}{l}0.02 \\
3\end{array}$ & Take effect \\
\hline$\left(\mathrm{X}_{2}\right)$ & -0.710 & $\begin{array}{l}- \\
0.34 \\
7\end{array}$ & $\begin{array}{l}0.72 \\
9\end{array}$ & No effect \\
\hline$\left(\mathrm{X}_{3}\right)$ & 7.992 & $\begin{array}{l}3.66 \\
7\end{array}$ & $\begin{array}{l}0.00 \\
0\end{array}$ & Take effect \\
\hline \multicolumn{5}{|c|}{ Constant $=50.774$} \\
\hline \multicolumn{5}{|c|}{ Adjusted $\mathrm{R}^{2}=0.051$} \\
\hline \multicolumn{5}{|c|}{ F hit $=5.982$} \\
\hline \multicolumn{5}{|c|}{ Dependent Variable: Environmental Care Character } \\
\hline
\end{tabular}

From the data above, the regression equation is formed as follows:

$Y=50.774+0.304 X_{1}-0.710 X_{2}+7.992 X_{3}$

Information:

\section{$Y=$ Environmental Care Character \\ $X_{I}=$ emotional intelligence \\ $X_{2}=$ moral intelligence \\ $X_{3}=$ intellectual intelligence}

Hypothesis testing in this study using multiple regression analysis. In multiple regression testing, the independent variables are said to have an independent effect on the dependent variable if the value of $t$ count $>$ $t$ table (1.969) or if the value of sig. has a value less than 0.05 . Likewise, when testing together, the independent variables are said to have a joint effect on the dependent (1yariable if the calculated $\mathrm{F}$ value $>\mathrm{F}$ table (2.638) or if the sig value. on has a value less than 0.05 . The following are the results of testing using multiple linear regression. The analysis data describe in table and bar chart below.

Tabel 3 . Primary Data Recapitulation

\begin{tabular}{|l|l|l|l|l|}
\hline School & $\begin{array}{l}\text { Emotional } \\
\text { Intelligenc } \\
\text { e (X1) }\end{array}$ & $\begin{array}{l}\text { Moral } \\
\text { Intellig } \\
\text { ence } \\
(\mathrm{X} 2)\end{array}$ & $\begin{array}{l}\text { Intellec } \\
\text { tual } \\
\text { Intellig } \\
\text { ence } \\
(\mathrm{X} 3)\end{array}$ & $\begin{array}{l}\text { Environ } \\
\text { mental } \\
\text { care } \\
\text { characte } \\
\text { r(Y) }\end{array}$ \\
\hline $\begin{array}{l}\text { SDN } \\
\text { Kowan } \\
\text { gan }\end{array}$ & 80.80 & 34 & 32 & 91.97 \\
\hline $\begin{array}{l}\text { SD IT } \\
\text { Paraka } \\
\text { n }\end{array}$ & 79.87 & 18 & 10 & 71.36 \\
\hline $\begin{array}{l}\text { SDN } \\
\text { Muntun } \\
\text { g }\end{array}$ & 82.04 & 31 & 31 & 83.61 \\
\hline $\begin{array}{l}\text { SD } \\
\text { Islam } \\
\text { Ngadir } \\
\text { ejo }\end{array}$ & 79.08 & 6 & 2 & 45.70 \\
\hline $\begin{array}{l}\text { SD N 2 } \\
\text { Kedu }\end{array}$ & 78.44 & 26 & 12 & 65.56 \\
\hline
\end{tabular}

from the data above can be described in a bar chart

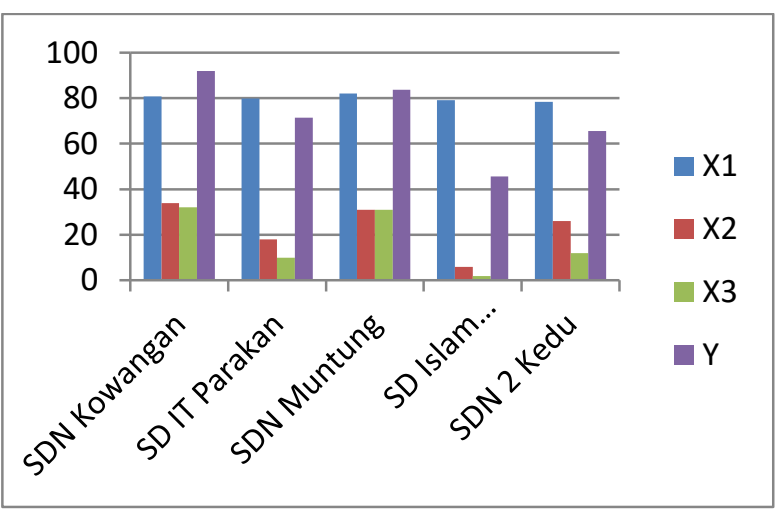

Figure 1. Recapitulation Environmental Care Character

The first hypothesis states that there is a positive influence of emotional intelligence on the environmental care character of elementary school students in Temanggung. The results of linear regression analysis between emotional intelligence (X1) and environmental care character $(\mathrm{Y})$ obtained the $\mathrm{t}$ count of 2.279 and the value of sig. of 0.023 , which means the value of $t$ count $>t$ table (1.969) and the value of sig. $<0.05$. These values prove that the emotional intelligence data supports the acceptance of the first hypothesis. The positive value on t count means that the influence of emotional intelligence on the character of caring for the environment is directly proportional. The greater the emotional intelligence 
possessed by students, the higher the environmental care character possessed by students.

The second hypothesis states that there is an influence of moral intelligence on the environmental care character of elementary school students in Temanggung. The results of linear regression analysis between moral intelligence and visual moral intelligence dummy data ( X2) on environmental care characters (Y) obtained the $\mathrm{t}$ count of -0.347 and the value of sig. 0.729 , which means the value of $t$ count $<t$ table (1.969) and the value of sig. $>0.05$. These values prove that the moral intelligence data does not support the acceptance of the second hypothesis, so it can be concluded that there is no influence of moral intelligence on the environmental care character of elementary school students in Temanggung.

The third hypothesis states that there is a positive influence of intellectual intelligence on the environmental care character of elementary school students in Temanggung. The results of linear regression analysis between intellectual intelligence and environmental care character $(\mathrm{Y})$ obtained the $\mathrm{t}$ count of 4.298 and the value of sig. 0.000 , which means the value of $t$ count $>t$ table (1.969) and the value of sig. $<$ 0.05. These values prove that the intellectual intelligence data supports the acceptance of the third hypothesis. The positive value on t count means that the influence of intellectual intelligence on the character of caring for the environment is directly proportional. Students who have high intellectual intelligence have a higher environmental care character than students with less intellectual intelligence [26].

The fourth hypothesis states that there is a joint influence of emotional intelligence, moral intelligence and intellectual intelligence on the environmental care character of elementary school students in Temanggung. Based on the test results, it is known that the calculated $\mathrm{F}$ value is 5.982. The calculated $\mathrm{F}$ value is already greater than the table $\mathrm{F}$ value (2.638), so the data supports the acceptance of the fourth hypothesis. Emotional intelligence, moral intelligence and intellectual intelligence together affect the environmental care character of elementary school students in Temanggung. It is also supported sig value. of 0.001 , or less than 0.05 .

\section{CONCLUSION}

There is a positive influence of emotional intelligence on the environmental care character of elementary school students in Temanggung. This is indicated by the t-count value of $2.279(>1.969)$ and a significance value of $0.023(<0.05)$. So it can be interpreted that the higher the emotional intelligence possessed by students, the higher the environmental care character they have. Vice versa, the lower the emotional intelligence possessed by students, the lower the environmental care character they have.

There is no influence of moral intelligence on the environmental care character of elementary school students in Temanggung. This is indicated by the $t$ arithmetic value of $-0.347(<1.969)$ and a significance value of $0.729(>0.05)$. So it can be interpreted that whatever the moral intelligence possessed by students, will not have any effect on the character of caring for the environment of students. There is a positive influence of intellectual intelligence on the environmental care character of elementary school students in Temanggung.

This is indicated by the t-count value of 3.667 ( $>$ $1.969)$ and a significance value of $0.000(<0.05)$. So it can be interpreted that the more students who have high intellectual intelligence, the higher the environmental care character of elementary school students in Temanggung. Vice versa. Taken together, there is a positive influence of emotional intelligence, moral intelligence and intellectual intelligence on the environmental care character of elementary school students in Temanggung. This is indicated by the calculated $F$ value of $5.982(>2.638)$ and a significance value of $0.001(<0.05)$.

\section{ACKNOWLEDGMENTS}

Thank you to LPDP Ministry of Finance of the Republic of Indonesia for funding this research. Thank you also to all elementary schools in Temanggung district who helped carry out this research. Thanks to the promoter team, Prof. Dasim Budimansyah, M. Si., Prof. Sapriya, M. Ed., and Dr. Rahmat, M. Si. for his guidance and knowledge and character education taught and trained to me. Thanks for civic education departemant and ACEC team. Thanks also to all parties that I cannot mention one by one who have helped me a lot in this research.

\section{REFERENCES}

[1] Douglas Schuler. Cultivating Society's Civic Intelligence: Patterns for a New "World Brain", Journal of Society, Information and Communication. Vol 4 No. 2, 2004

[2] W. A. Galston, Liberal Purposes: Goods,Virtues and Diversity in the Liberal State. Cambridge: Cambridge University Press, 1991.

[3] UNESCO. Education for people and planet: Creating Sustainable Future for All. In Global Education Monitoring Report 2016.

[4] Dauglas Schuler. "Pieces of Civic Intelligence: Towards a Capacities Framework"E-Learning and Digital Media. 2014. 11(5), 518-529. 
[5] Dasim Budimansyah. Penguatan Pendidikan Kewarganegaraan Untuk Membangun Karakter Bangsa. Bandung: Widya Aksara Press. 2010.

[6] Hernandes, R. V., Alcántara, L., \& Limón, D. The complexity of environmental education: Teaching ideas and strategies from teachers. 237(2017), 968-974. doi:10.1016/j.sbspro.2017.02.137.

[7] B. Ghebru and M. Lloyd, "From civic to citizenship education: Toward a stronger citizenship orientation in the Ethiopian CEE curriculum," International Journal of Educational Development, vol. 72, p. 102143, 2020.

[8] T. Semela, T. Bohl, and M. Kleinknecht, "Civic Education in Ethiopian schools: Adopted paradigms, instructional technology, and democratic citizenship in a multicultural context," International Journal of Educational Development, vol. 33, no. 2, pp. 156-164, 2013.

[9] Michele Borba. Membangun Kecerdasan Moral : Tujuh Kebajikan Utama untuk Membentuk Anak Bermoral Tinggi. Diterjemahkan oleh Lina Jusuf. Jakarta : PT Gramedia Pustaka Utama. 2008.

[10] L. J. Quaynor, "Researching citizenship education in Africa: Considerations from Ghana and Liberia," Research in Comparative \& International Education, vol. 10, no. 1, pp. $120-$ 134, 2015.

[11] A. Buck and B. Geissel, "The education ideal of the democratic citizen in Germany," education, citizenship and social justice, vol. 4, no. 3, pp. 225-243, 2009.

[12] John Dewey. Experience and education. Educational Forum. https://doi.org/10.1080/00131728609335764, 1986.

[13] John Dewey. The public and its problems. In The Civil Society Reader. https://doi.org/10.5840/newscholas 19282253 , 2003

[14] John Dewey. How we think. In How we think. https://doi.org/10.1037/10903-000, 2006.

[15] Yilmaz-Soylu, Meryem., \& Akkoyunlu, Buket. The effect of learning style on achievement in different learning environments. The Turkish Online Journal of Education Technology,2002. 43-50.

[16] Prashnig, Barbara. The power of diversity: New ways of learning and teaching through learning styles. (Terjemahan Nina Fauziyah). Stafford: Network Educational Press Ltd, 2007.

[17] K. A. Nishikawa, "Bridging the Participation Gap with Government-sponsored Neighborhood Development Programs: Can Civic Skills be
Taught?," Journal of Politics in Latin America, vol. 4, no. 2, pp. 63-87, Aug. 2012.

[18] T. W. W. Yuen, "Civic Education stuck in a quagmire: A critical review of Civic Education in Hong Kong?," Citizenship, Social and Economics Education, vol. 15, no. 2, pp. 69-82, May 2016.

[19] Bocian, K., Baryla, W., Kulesza, W. M., Schnall, S., \& Wojciszke, B. (2018). The mere liking effect: Attitudinal influences on attributions of moral character. Journal of Experimental Social Psychology, 79(2018), 9-20. doi:10.1016/j. jesp.2018.06.007.

[20] A. Dobson. Environmental citizenship: Towards sustainable development. Sustainable Development. $\quad$ https://doi.org/10.1002/sd.344. 2007.

[21] A. Dobson. Environmental citizenship and proenvironmental behaviour. Rapid research and evidence review. Keele university, Staffordshire united Kingdom. 2010.

[22] M. Murdiono., Miftahuddin, M., \& Kuncorowati, P. W. The education of the national character of pancasila in secondary school based on pesantren. Cakrawala Pendidikan, 2017. 36(3), 423-434. doi:10.21831/cp.v36i3.15399.

[23] D. Schulz, Wolfram, Fraillon, Julian, Ainley, John, Losito, Bruno, Kerr, International Civic and Citizenship Education Study. Amsterdam: IEA, 2008.

[24] C. Antal and P. Easton, "Indigenizing Civic Education in Africa: Experience in Madagascar and the Sahel," International Journal of Educational Development, vol. 29, no. 6, pp. 599-611, 2009.

[25] Wagiran. Metodologi penelitian pendidikan (teori dan implementasi).Yogyakarta: Deepublish, 2014.

[26] Kahriman-Pamuk, D., \& Ahi, B. A phenomenological study on the school concept of the children attending the forest school. Journal of Qualitative Research in Education, 2019, 7(4), 1386-1407. doi: 10.14689/issn.21482624.1.7c.4s.4m. 